\title{
The sixteenth century panel Virgin with the Child and an Angel, confluences of material characterization and iconography
}

\author{
Eva Marín, Jose Francisco Garcia* \\ Analytical Chemistry Department Chemistry Faculty, University of Barcelona, C/Diagonal 645, 08028 Barcelona, Spain
}

\section{A R T I C L E I N F O}

\section{Article history:}

Received 27 December 2016

Accepted 6 September 2017

Available online $\mathrm{xxx}$

\section{Keywords:}

Flemish mannerism

Jan Massys

Materials characterization

LA-ICP/MS

Verditer

Smalt

Museu d'Art de Girona

\begin{abstract}
A B S T R A C T
Attribution of the panel The Virgin with the Child and an Angel today in the Art Museum of Girona is under study due to the existence of two hypotheses, both of them not thoroughly documented, pointing Jan Massys and Bernardo Luini as potential authors. Attribution process is an important issue in many museums and collections. In this article, the question is addressed by combining material and iconographic information, paying special attention to the information yielded by minor components, and by following the material characteristics of the existing restoration interventions. In addition to imaging and classical analytical techniques (SEM and FTIR), the capability of a new developed Laser Ablation-Inductively Coupled Plasma-Mass Spectrometry system for minor elements and thin layers detection is also discussed. Results confirmed a 16th century palette and revealed the use of specific pigments such as Verditer and Smalt. Analytical results combined with iconographic characteristics, permitted the contextualization of the painting in North Europe in the circle of production of Antwerp between 1500-1550. This conclusion does not allow the direct attribution to Jan Massys but minimize the probabilities of Bernadino Luini as author.
\end{abstract}

(c) 2017 Elsevier Masson SAS. All rights reserved.

\section{Introduction}

The painting Virgin with the Child and an Angel is today part of the permanent collection of the Art Museum of Girona, together with other representative paintings of the local Northern Catalan Renaissance of the 16th century. The old catalogue pointed out to the Italian Benardino Luini as the author although recently, it has also considered the candidacy of the Flemish painter Jan Massys.

Bernardino Scapi, o de Scapis, also known as Bernardino Luini (ca 1480-1532), was a North Italian conservationist painter from Leonardo's circle. He was known for his graceful female figures and celebrated for his mythological and biblical themes [1]. He is considered one of the most significant Milanese painters of the Italian Renaissance although little is known of his life.

Jan Massys, also known as Jan Matsys or Metsys, (ca1510, Antwerp-8 October 1575, Antwerp) was a Flemish Renaissance painter known for his history paintings, genre scenes and landscapes. He trained under the guidance of his father Quentin Matsys, an already important painter founder of the Antwerp School. In 1544, Jan Massys was banned from Antwerp and started an obscure 10 years period travelling. He returned to

\footnotetext{
* Corresponding author.

E-mail address: jfgarcia@ub.edu (J.F. Garcia).
}

Antwerp before the end of 1555 living there until his death [2]. During the first period before his exile, he collaborated with his father and developed a very similar style. From this period, few painting are attributed with certainty. The first dated painting is a St. Jerome in his cell (1537), which is completely in his father's style [2]. From the second period, little is known and only two paintings bear a signature and a date, both from 1552 entitled Virgin with Child and Nativity. Finally, from his last period back in Antwerp, most of the paintings are signed and dated and, therefore, do not present problems regarding authorship.

Both artists proposed have some unclear stories and little documentation is available. This situation complicates the objective of achieving a contextualization of the painting under study.

\section{Research aims}

Attribution can be considered a quite common problem faced by many museums and collections professionals. The article is focused on the research process followed to recollect all the available evidences that permit the contextualization of the panel. In particular, the objective is to combine the information related to the material composition and the iconographic characteristics of the panel aiming to give some light about the potential author. During the analysis it became of paramount importance the acquisition of minor components information using sensitive techniques such as 
the LA-ICP/MS, specifically developed for the study of large artworks.

Among the different techniques based on the use of a laser as a micro-sampling tool, LA-ICP/MS has proven itself as a powerful option, which provides isotopic information of the elements selected in a large range of concentrations due to the low detection limit of the detector [3-5]. Despite the fact that LA-ICP/MS requires the use of an ablation cell to collect the material ablated, which can complicate the calibration process, the deterioration produced is minimum originating ablation craters of 100-200 microns of diameter, not visible at the naked eye and disclosing the stratigraphy beneath the surface.

Despite its potential capabilities, there are no commercially available instruments for LA-ICP/MS, including ablation cells, that permit the direct analysis of large objects like artworks. Concerned by this limitation, few approaches have been developed recently mainly focused on the design of prototypes with open cells that could be placed on the object surface [6-8]. However, most of these application tests have been performed on metallic, ceramic or glass artwork but in practice, studies about its application to the analysis of paintings are not available [5-7,9-13].

To accomplish this goal, a specific optical system and ablation cell were designed and coupled to the ICP/MS. The capability of the developed LA-ICP/MS system for the analysis of paintings was evaluated in terms of damage produced on the artwork and its potential for stratigraphic composition determination. Results by LA-ICP/MS for the determination of very thin layers in easel painting (taking advantage of the low detection limit of the ICP/MS technique) were compared with those obtained by SEM-EDX.

\section{The painting}

The painting (MdA250.256) is composed of one single panel $(74 \times 75 \mathrm{~cm})$ depicting a principal figurative group in the forefront composed by The Virgin and the Child together with an Angel. Behind the figures, in the background, it is possible to distinguish two areas: a dark and shapeless area which encompasses the figures, most likely result of an over painting; and the opposite light area where an architectural landscape can be observed. Regarding the palette it seems important to point out the execution of the Virgin dress in a dark brownish colour, a characteristic not very commonly found in 16th century iconography (Fig. 1).

Visual examination of the panel clearly indicates the presence of undocumented restorations performed in the past. The support presents a good state of preservation and has been complemented with the addition of a cradle. In addition, partial reduction of the support can be observed by the left lateral and the lower margin. Inspection of the overall surface highlighted the thinness of ground and painting layers and showed the presence of numerous areas of original material loose, intervened in the form of big retouching areas done in a neutral tone together with some punctual retouching carried out in an illusionistic manner. The surface appears slightly matt at normal illumination probably due to the application of a modern varnish.

The existing documentation is limited but includes the traditional attribution to Bernadino Luini but also the suggestion made by Dr. T. Faggin in the 80 s, who considered the painting stylistically similar to the Jan Massys' panel Holly Family with Saint Elisabeth (ca. 1520 Carneige-Museum of Art, Pittsburgh) [14]. Even though the current attribution gives the authorship to the latter, one of the most important research undertaken in Jan Massy's life, published
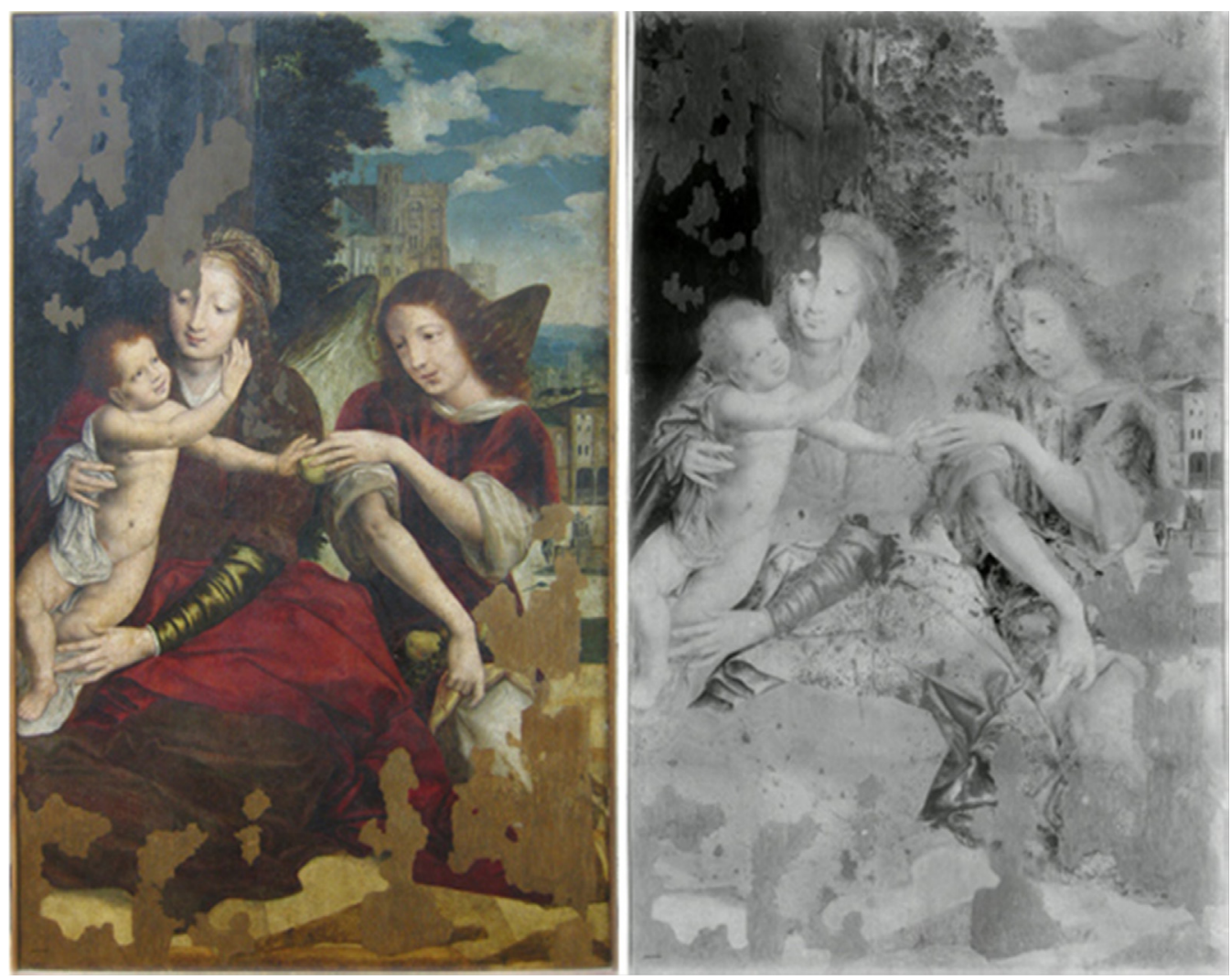

Fig. 1. Virgin with the Child and an Angel Left: Visible image; Right: Infrared Reflectography.

Please cite this article in press as: E. Marín, J.F. Garcia, The sixteenth century panel Virgin with the Child and an Angel, confluences of material characterization and iconography, Journal of Cultural Heritage (2017), http://dx.doi.org/10.1016/j.culher.2017.09.006 
in 90s by Dr. L. Buijnsters-Smets [2], does not included the panel in its list of productions.

\section{Materials and methods}

\subsection{Technical examination}

Technical examination was focused on the characterization of the painting materials both original and those added in previous restoration. Special attention was paid to the minor components in order to detect singular features of the modus operandi of the unknown artist.

The study of the object includes:

- global imaging techniques: visible light and raking light, UV radiation, Infrared Reflectography and X-radiography;

- punctual analysis of major components with sample extraction: Scanning Electron Microscopy (SEM/EDX) for the elemental analysis and micro Mid-Infrared Spectroscopy (FTIR) for the determination of organic and some inorganic compounds (detailed information of the protocols can be found in the Supplementary material);

- punctual analysis of minor components and their stratigraphic distribution using a specific Laser Ablation-Inductively coupled Plasma Mass Spectroscopy (LA-ICP/MS).

\subsection{LA-ICP/MS operating system description}

This new system allows to locate an open ablation cell at any position onto the painting surface. Successive laser pulses on the same spot generate an aerosol of material (stratigraphy) from the sample producing a deterioration not detectable at naked eye. The main differences expected from LA-ICP/MS versus SEM are its capability to evidence the existence and location of thin layers and the detection of minor elements across the stratigraphy due to its better detection limit [15].

The LA-ICP/MS analyses were conducted directly using a quadruple Perkin Elmer Elan 6000, coupled to an experimental laser ablation system. The nebulizer was removed to connect the ablation system directly to the torch injector. The measurements were performed in the dual detection mode of the instrument, which offers the measurement of pulse counting and analogue signals simultaneously ( $r f$ power $1150 \mathrm{~W}$, dwell time $10.0 \mathrm{~ms}$, number sweeps 10 , gas flow $0,7 \mathrm{~L} / \mathrm{min}$ ). Isotopes selected were chosen according to the expected composition of the different paint layers analyzed (corresponding to previous SEM-EDX results). These were: Al27, Ca44, Ti47, Fe56, Co59, Cu65, Zn66, As75, Ba137, Hg202, Pb208.

An external optical system was used to focus the radiation on the artwork surface. The system also incorporated a camera CMOS Color Pixelink (Model PL-B742U), which allows for the observation of the ablation process in real time on a PC screen. The laser used was a Brilliant Nd:YAG (1064 nm) with FHG to $266 \mathrm{~nm}$. Laser beam characteristics were: initial energy $4,72 \mathrm{~mJ}$, frequency $2 \mathrm{~Hz}$, beam diameter 100 microns.

This system uses a sample chamber (ablation cell of $17 \times 4 \mathrm{~cm}$ and $27.96 \mathrm{~g}$ ) with an open bottom design, that can be placed directly onto the painting and moved freely over its surface (design University of Barcelona). The impact of successive laser pulses on the same spot generates an aerosol of material from the sample producing a minimum deterioration on the object $\left(100 \mu \mathrm{m}^{2}\right.$ diameter and $5-10 \mu \mathrm{m}$ of thickness).

The carrier gas (Ar) was introduced through an inlet nozzle at a constant flow $(0.7 \mathrm{~L} / \mathrm{min})$ that was able to carry away the laserinduced aerosol. The sample chamber's gas outlet is connected to the rear termination of the ICP with a PVC tube (transportation system).

\section{Results}

\subsection{Structure and material composition}

The first approach to the painting was made using nondestructive imaging techniques. X-ray examination indicates the absence of any underneath composition. Raking light highlighted the flatness of the painting as well as slight aging craquelures. UVinduced visible fluorescence showed some greenish-white visible fluorescence in the Virgin's dress area and the presence of some overpainted areas along the entire painting.

Infrared reflectography allowed the observation of the underdrawing done in a black medium (Fig. 1). Contours and main folds are established by fine lines while hatching and washes are almost not present. No numerous shifts in the outer contours of the figures no corrections are present and definition of the faces is restricted to essential features (detailed IRR-image can be found in the Supplementary material). These features likely indicate the use of an independent preliminary drawing.

IRR-image also clearly showed big areas of retouching and some dense hatching located mainly in the Angel vestments similar to these found in the red cloak. Some difference in absorption between the upper and the lower parts of the white drapery around the child was also observed.

These first results allowed for the localization of most of the treated/restored areas, facilitating the sampling procedure. Also, indicate some potential key areas of analysis such as the Virgin's dress and the Child's white drapery. The material composition disclosure was focused on the determination of the different coloured areas. Samples were taken representatively from white areas, carnations, reds, browns and background (Fig. 2 and Table 1). Results in both, original and non original areas are given when necessary, while the complete description of the analysis can be found in the Supplementary material.

From the bottom to the surface, the structure of the painting includes:

- a preparatory layer, composed by Calcium Carbonate with animal glue as binder;

- a copper-based imprimatura (detected by LA-ICP/MS and not by SEM-EDX) that suggested the use of Verditer although other copper-based pigments (Azurite or Verdigris) cannot be excluded;

- a paint layer including a drying oil and different pigments according to the colour of the area.

The surface layer was not clearly identified, but some results from FTIR spectra showed the presence of a natural resin. However, all the samples analysed by LA-ICP/MS contained in the most external part a significant amount of Zn, most probably Zinc White, included as a siccative in the varnish and responsible for the mate appearance of the painting.

Results corresponding to the pigments composition are shown grouping the samples by colours. Due to extension reasons, most of the information is included in Table 1 and in the Supplementary material. However, for attribution purposes and novelty of the analytical technique used is important to highlight the results corresponding to two areas: the Brown area, original Sample (F4, Fig. 2) located in the dress of the Virgin; and the White drapery around the Child's body (D1 upper part and D2 downer part of the drapery) compared to other whites in the composition (D3 from the angel's tunic and D4 from a cloud in the sky, Fig. 2). 

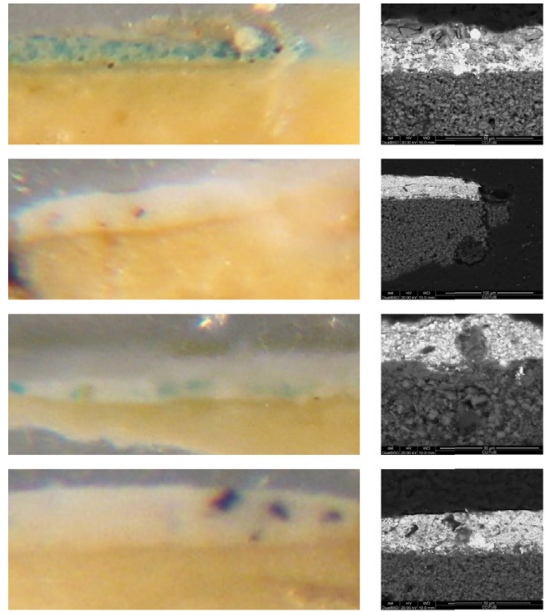

F4
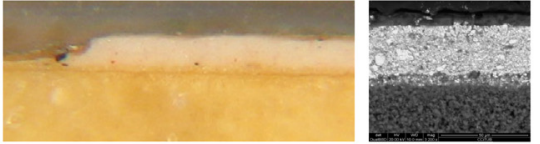

D5

D3
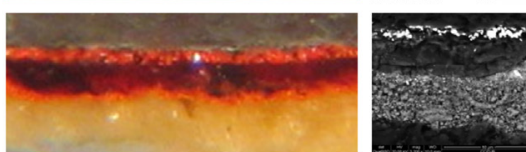

E1
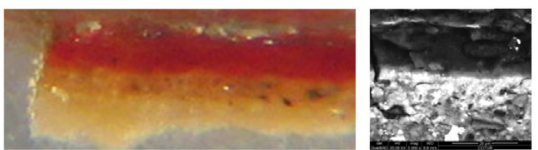

$\mathrm{F} 2$
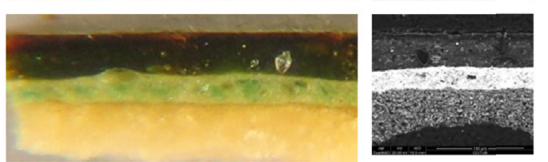

F6

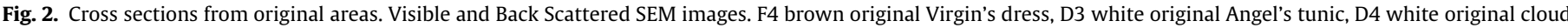
sky, D1 white original Child's drapery, D5 carnation original, E1 red original Virgin's cloak, F2 red original Angel, and F6 brown original background.

Table 1

Results on the different colour areas analysed.

\begin{tabular}{|c|c|c|c|c|c|c|}
\hline Color & Sample & $\mathrm{o} / \mathrm{n}$ & Pigments & SEM $^{\mathrm{a}}$ & FTIR $^{\mathrm{b}}$ & LA-ICPMS \\
\hline \multirow[t]{4}{*}{ Whites } & D3 & o & Lead White ${ }^{\mathrm{a}, \mathrm{b}, \mathrm{c}}$, Smalt $^{\mathrm{c}}$, copper-based pigment ${ }^{\mathrm{c}}$ (Verditer) & $\mathrm{x}$ & $\mathrm{x}$ & $\mathrm{x}$ \\
\hline & D4 & 0 & Lead White ${ }^{\mathrm{a}, \mathrm{b}}$, Verditer $^{\mathrm{b}}$ & $\mathrm{x}$ & $\mathrm{x}$ & \\
\hline & D1 & $\mathrm{n}$ & Lead White ${ }^{\mathrm{a}, \mathrm{b}, \mathrm{c}}$, copper-based pigment ${ }^{\mathrm{c}}$ (Verditer) & $\mathrm{x}$ & $\mathrm{x}$ & $\mathrm{x}$ \\
\hline & D2 & $\mathrm{n}$ & Lead White ${ }^{\mathrm{b}}$, Calcium Sulphate ${ }^{\mathrm{a}, \mathrm{b}}$ & $\mathrm{x}$ & $\mathrm{x}$ & \\
\hline \multirow[t]{2}{*}{ Carnations } & D5 & o & $\begin{array}{l}\text { Lead White }{ }^{\mathrm{a}, \mathrm{b}, \mathrm{c}} \text {, aluminium-based pigment }{ }^{\mathrm{c}} \text { (red lake) } \\
\text { Vermilion }^{\mathrm{c}} \text {, iron-based pigment }\end{array}$ & $\mathrm{x}$ & $\mathrm{x}$ & $\mathrm{x}$ \\
\hline & D6 & $\mathrm{n}$ & $\begin{array}{l}\text { Lead White } e^{\mathrm{a}, \mathrm{b}, \mathrm{c}} \text { aluminium-based pigment }{ }^{\mathrm{c}} \text { (red lake) } \\
\text { Vermilion }^{\mathrm{c}} \text {, copper-based pigment }{ }^{\mathrm{c}} \text { (Verditer) }\end{array}$ & $\mathrm{x}$ & $\mathrm{x}$ & $\mathrm{x}$ \\
\hline \multirow[t]{4}{*}{ Reds } & E1 & 0 & $\begin{array}{l}\text { Lead White }{ }^{\mathrm{a}, \mathrm{b}, \mathrm{c}} \text {, iron-based pigment }{ }^{\mathrm{c}} \text {, aluminium-based } \\
\text { pigment }^{\mathrm{a}, \mathrm{c}} \text { (red lake) copper-based pigment }{ }^{\mathrm{c}} \text { (Verditer) }\end{array}$ & $\mathrm{x}$ & $\mathrm{x}$ & $\mathrm{x}$ \\
\hline & $\mathrm{F} 1$ & $\mathrm{n}$ & $\begin{array}{l}\text { Lead White }{ }^{\mathrm{a}, \mathrm{c}}, \text { Vermilion }^{\mathrm{a}, \mathrm{c}} \text {, aluminium-based pigment }{ }^{\mathrm{a}, \mathrm{c}} \\
\text { (red lake) copper-based pigment }{ }^{\mathrm{c}} \text { (Verditer) }\end{array}$ & $\mathrm{x}$ & $\mathrm{x}$ & $\mathrm{x}$ \\
\hline & $\mathrm{F} 2$ & 0 & Carmine Lake ${ }^{\mathrm{a}, \mathrm{b}, \mathrm{c}}$, lead-based pigment $\mathrm{t}^{\mathrm{a}, \mathrm{c}}$ & $\mathrm{x}$ & $\mathrm{x}$ & $\mathrm{x}$ \\
\hline & F3 & $\mathrm{n}$ & $\begin{array}{l}\text { Vermillion }^{\mathrm{c}} \text {, lead-based pigment }{ }^{\mathrm{a}, \mathrm{c}}, \text { Barium Sulphate }{ }^{\mathrm{a}, \mathrm{b}, \mathrm{c}} \\
\text { (Lithopone), aluminium-based pigment }^{\mathrm{a}, \mathrm{c}} \text { (red lake) } \\
\text { (cobalt and arsenic compound found underneath) }^{\mathrm{c}}\end{array}$ & $\mathrm{x}$ & $\mathrm{x}$ & $\mathrm{x}$ \\
\hline \multirow[t]{2}{*}{ Browns } & F4 & 0 & $\begin{array}{l}\text { Lead White }{ }^{\mathrm{a}, \mathrm{b}, \mathrm{c}}, \text { Verditer }^{\mathrm{a}, \mathrm{b}, \mathrm{c}}, \text { Smalt } \\
\text { aluminium-b, Vermilion } \\
\text {, }\end{array}$ & $\mathrm{x}$ & $\mathrm{x}$ & $\mathrm{x}$ \\
\hline & D7 & $\mathrm{n}$ & Silicium-based pigments a & $\mathrm{x}$ & $\mathrm{x}$ & $\mathrm{x}$ \\
\hline \multirow[t]{3}{*}{ Back-grounds } & F6 & o & $\begin{array}{l}\text { Calcium Carbonate }{ }^{\mathrm{a}, \mathrm{b}} \text {, lead-based pigment }{ }^{\mathrm{a}, \mathrm{c}} \text {, copper-based } \\
\text { pigment }^{\mathrm{a}}\left(\text { Verditer }^{\mathrm{b}}\right)\end{array}$ & $\mathrm{x}$ & $\mathrm{x}$ & \\
\hline & F5 & $\mathrm{n}$ & $\mathrm{N} \mathrm{I}$ & $\mathrm{x}$ & $\mathrm{x}$ & \\
\hline & F7 & 0 & Lead White ${ }^{\mathrm{a}, \mathrm{b}, \mathrm{c}}$, Verditer $^{\mathrm{a}, \mathrm{b}, \mathrm{c}}$, calcium-based compound $^{\mathrm{a}, \mathrm{c}}$ & $\mathrm{x}$ & $\mathrm{x}$ & $\mathrm{x}$ \\
\hline
\end{tabular}

Samples location, colour indication, together with major and minor elements detected by each technique used (o/n column: original and non original areas).

Concerning the Virgin's dress, original F4 sample allowed the identification of a complex brown mixture on the surface but blue underneath (F4, Fig. 2). Analyses by SEM-EDX clearly differentiate three layers in the stratigraphy: ground ( $\mathrm{Ca}$ ), painting ( $\mathrm{Pb}, \mathrm{Ca}, \mathrm{Si}, \mathrm{Al}$, $\mathrm{As}, \mathrm{Cu}, \mathrm{Fe}$ and $\mathrm{Co}$ ) and surface. Results by FTIR on the painting layer identified Verditer $\left(\mathrm{CuCO}_{3} \cdot \mathrm{Cu}(\mathrm{OH})_{2}\right.$, Copper(II) hydroxide bands: $3433,1518,975$ and $840 \mathrm{~cm}^{-1}$, Fig. 3) as partially responsible of the blue colour. Another important absorption from another spot of the same sample at 1000 and $1200 \mathrm{~cm}^{-1}$ could be associated to the presence of Silica which can hinder the presence of Smalt, although this result was not conclusive and was confirmed by the combination with other techniques.

Laser Ablation-ICP/MS technique applied to an area close to sample F4 confirms the stratigraphical sequence observed previously and gives additional information about the distribution of minor elements. Fig. 4 shows the distribution of signals obtained along the cross-section by plotting the results obtained for the successive laser pulses on the area analysed. Plots represent in the abscissa each laser pulse in depth and in the ordinates an arbitrary normalised signal intensity. Elements are organized in groups according to their position in the stratigraphy or their relevance.

Fig. 4. a shows the signal of the two major elements detected, $\mathrm{Pb}$ related to the painting layer and Ca to the ground. As it can be seen in the Figure, the fraction of the plot related to the painting layer is placed between the beginning of the signal of $\mathrm{Pb}$ and the signal of $\mathrm{Ca}$, located between 10-30 lectures of the abscise, corresponding approximately to $20 \mu \mathrm{m}$ of thickness based on the width observed in the cross-section by SEM.

A zoom in this range (Fig. 4.b, c, d) allows differentiating three layers: a superficial one defined by the signals of $\mathrm{Zn}, \mathrm{Fe}$ and $\mathrm{Pb}$, followed by a sub strata slightly inferior indicated by the presence of $\mathrm{Al}$ and $\mathrm{Hg}$. Then a painting layer including $\mathrm{Pb}$ but accompanied by As and Co. Finally, the ground layer formed by two different strata, a priming layer pointed by the signal of $\mathrm{Cu}$ and a preparation of Ca.

According to the results obtained by all the techniques, the dress is composed by a mixture of Lead White, Verditer and Smalt which imply originally a shiny turquoise dress. Complementing these results, LA-ICP/MS disclosure of the stratigraphy indicated 


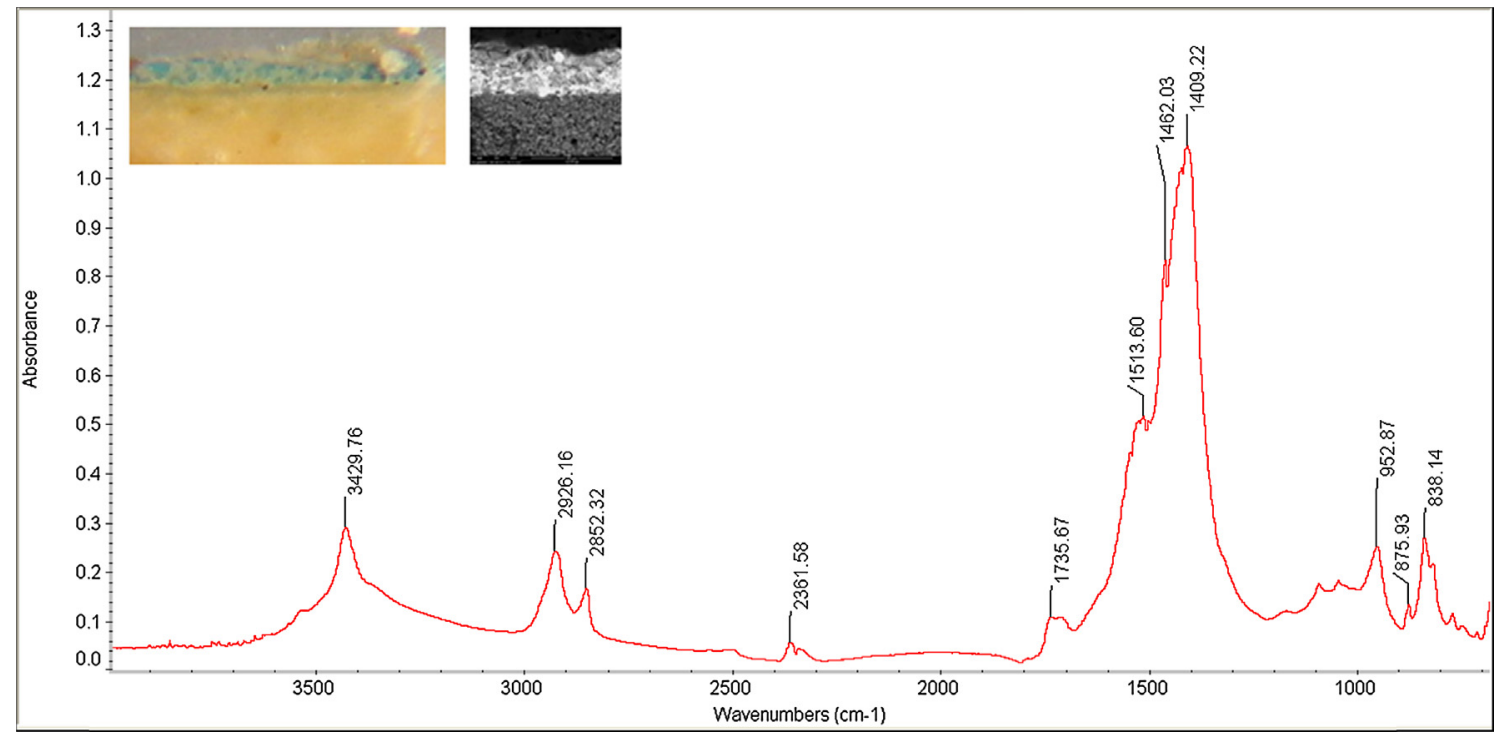

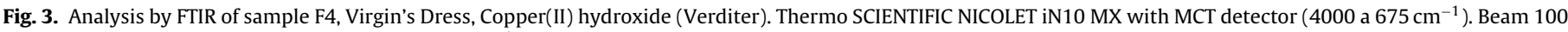
microns, number of scans 64 , spectral resolution $4 \mathrm{~cm}^{-1}$.
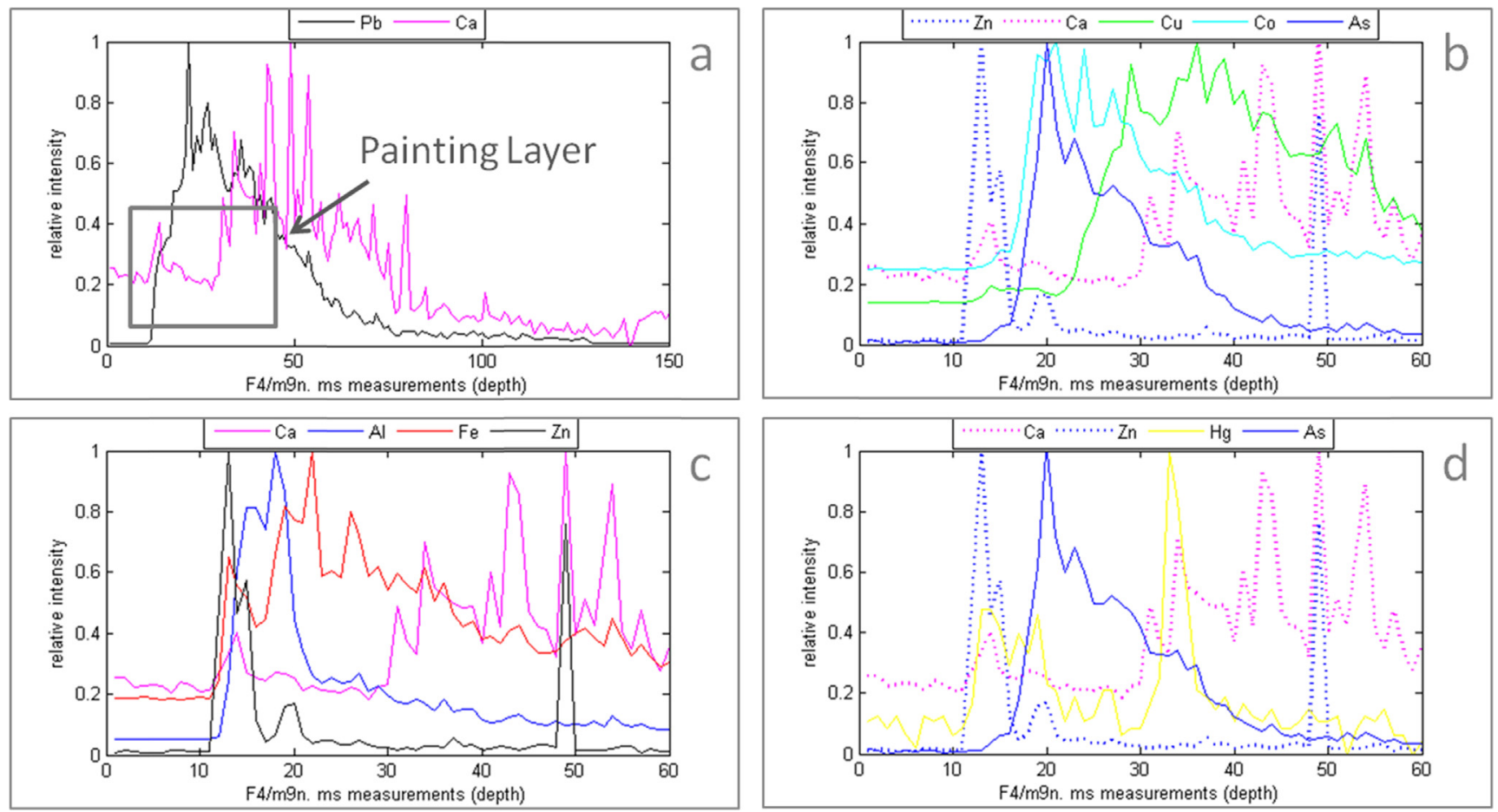

Fig. 4. Results obtained by LA-ICP/MS on sample F4; a: localization of the paint layer; b, c, d: detailed information about composition.

the presence also of an aluminium based pigment, most likely a lake, and a glaze of Vermillion on the surface.

Interpretation of the above results suggests that the presence of Smalt in oil medium may be the cause of the colour alteration of the pigment on the surface $[16,17]$ that would have been later restored using a glaze of a lake and Vermillion, responsible for today's brown dress.

On the other hand, results on the Child's white drapery identified a lead-based compound most probably Lead White detected by a high signal of $\mathrm{Pb}$ present in all the samples analysed by SEMEDX and corroborated by FTIR by the presence of a Lead Carbonate, most likely Hydrocerussite. Complementing the above-mentioned analysis, additional information by LA-ICP/MS allowed for the discrimination of the different areas studied. For example, results on the other two original white areas analysed (D3 from the angel tunic and D4 from a cloud in the sky, Fig. 2) showed the presence of a copper-based pigment such as Verditer, which was confirmed in a FTIR spectrum. However, clear signals of $\mathrm{Co}$ and As were detected by laser ablation only in the tunic, suggesting that the same mixture was used for all original whites, with the variation of the inclusion of some Smalt in the execution of this element.

Results obtained for the Child's drapery (D2 and D1, upper and downer parts) showed in the white paint of the downer part (D1 Fig. 2) the presence of $\mathrm{Cu}$ (similar to the results obtained in the cloud, D3), whereas in the upper part only $\mathrm{Ca}$ and $\mathrm{Pb}$ were found (D2). The combination with the other techniques clarified the 
contribution of Verditer for D1 and Calcium Sulphate for D2 together with Lead White. The overall results indicated therefore the presence of a small punctual retouching in the upper part of the white drapery which was already suggested in the IRR-image, and confirms the originality of this iconographic element against the initial hypothesis.

Carnations were studied in two different areas of the Angel figure: original from the arm (D5 Fig. 2); and a retouching from the dark side of the forehead (D6). Only laser ablation allowed for the identification of $\mathrm{Hg}$ and $\mathrm{Cu}$ signals in the area of the arm, which suggested the presence of Vermillion and a copper-based pigment, elucidating the difference between the two areas.

Reds were divided into two groups coming from the Virgin's red cloak (E1 and F1 Fig. 2) and from the Angels figure (F2 and F3 Fig. 2). In both cases including original and non-original areas. In this case, it is interesting the identification of Co and As in sample F3 (retouching), which point to the presence of Smalt in the lower part of the cross section of this area. This datum combined with the results on white pigments, suggests the presence of the angel's white wing underneath the shoulder, which matches the original composition of D3. This highlight the system capabilities for the in depth analysis with enough resolution to differentiate the superficial red layer and the white layer of the wing underneath.

Analysis on different parts of the background was performed in three different areas (F5 brown over painting, F6 indeterminate brown and original blue sky F7). Results on F6 and F7 indicates the presence of Lead White and Verditer in both samples, suggesting the presence of parts of blue sky under the dark over painting and again confirming the system potentialities for in depth stratigraphy detection (F6 Fig. 2).

\subsection{Historical background and iconography}

From the material point of view, the results obtained on the analysis of the Virgin with the Child and an Angel showed a total compatibility with the materials used in easel painting in 16th century [18]. The question about authorship is focused on the discrimination between the two possible authors through three main aspects: the ground layer based on Calcium Carbonate substrate, the priming layer and the use of some specific pigments such as Verditer and Smalt.

With regard to the ground layer, it is known how sixteenth century artists in the south used Gesso Grosso (Calcium Sulphate), whereas artists from the north used Calcium Carbonate [19-23].

Verditer is defined as a Copper Basic Carbonate $\left[2 \mathrm{CuCO}_{3} \cdot \mathrm{Cu}(\mathrm{OH})_{2}\right]$ and, in some cases, can be considered the synthetic equivalent to Azurite. Verditer was a cheap pigment not frequently found in artistic palettes and excluded from most of the old literature [24]. Its date of introduction as an artistic material is not clear. While Harley [25] asserted that it was relatively new in 17 th century, R.J. Gettens pointed out that it would be commercially available in a generalized manner at the end of 16th century [26]. A short reference can be found in a treatise by Théodore de Mayerne (1573-1655) but that might be a transcription from an older lost book and therefore, it could have been in use already during the 15th century. Conclusively it is a pigment that could have been discovered in France (under the old name verd de terre) at the end of 15 th century and been in use along 16th and 17th centuries.

Verditer can be found in some examples of Northern Renaissance painting such as the case of The Adoration of the Lamb by Jan van Eyck (1432) or in the altarpiece of Dieric Bouts The Holy Sacrament (1464-68) [27]. Also in the period of Jan Massys it is possible to find a reference of its use in a painting titled Job and his Comforters, attributed to Lucas van der Leyden, active in the Netherlands between 1503 and 1533 [28]. On the contrary important examples of Southern painting using this pigment have not been found [26].

Smalt, also known as Enamel blue, Saffer blue o Saxony blue, is considered one of the most popular blues from the second half of the 17th century up to the beginning of 19th together with the much appreciated Azurite and Ultramar, although of a lower quality. Its use decreased all along the 18th century most probably coinciding with the discovery of blues of better qualities such as Prussian Blue or Cobalt Blue [17,29,30]. Its date of introduction is not clear. It is not mentioned in the old literature, being one of the earliest reference from Borghini's Treatise in 1589 [29].

Despite its poor specific characteristics for painting, it was a very popular pigment. It has been suggested that its popularity coincides with a period of a shortage of Blue pigments during 16th and 17 th centuries $[17,29]$. This could be hinted by the examination of medieval account books of trading companies acting throughout Europe. The fact that ultramarine was not available in Germany during XVI century and Azurite tripled its price between 1488 and 1553 [31], induce Northern Artists to the experimentation with other blues, taking advantage of the existing mine of Cobaltite (CoAsS) and Smaltite ( $\left.\mathrm{CoAsS}_{2}\right)$ in Saxony (Germany) discovered and mined since 16th century. On the contrary, this effect would be less obvious in Southern countries, especially in Italy, where the trade in Venice was rich and had a direct incoming of Ultramar [30].

Regarding the attribution of the panel, the analysis of the paint mixtures on a painting titled The Pietà by the Master of Female Halflength documented in Antwerp between 1527 and 1540, showed the use of two main blues: Azurite for the very small areas such as lips and shades in violet colours; and Smalt in the cloak of the Virgin and big areas of the background. All of these areas today present a gray pale tone having lost almost all its bluish hue due to the degradation of the pigment in oil medium [32].

Taking into account the ground layer composition and the use of Verditer and Smalt it seems possible to locate the production of the panel in the north of Europe in a period which includes 16th and 17 th centuries.

From the iconographic point of view, the panel totally agrees with the canons of religious art of the period proposed. The current technical study has revealed the real colour of the dress of the Virgin (Blue dress and a red cloak) and the originality of the white drapery around the Child. A revision of these two key elements is proposed in a set of 100 paintings from South and North Europe executed between 1450 and 1650 (Fig. 5) (for a detailed list of paintings visit the Supplementary material).

Results concerning the colours of the Virgin showed that south Europe, and especially Italy, was very constant in depicting the Virgin Mary in a red dress covering her with a blue cloak. On the contrary North Europe, Dutch and German painting was less strict until the beginning of 16 th century when a confluence of style can be seen and the distribution of colours was just opposite to Italy, blue dress and red cloak (Fig. 5).

On the other hand, if a revision is done regarding the drapery around the Child again North and South take opposite positions. Thus, while Italy would depict the Child mainly uncovered, in the northern painting he would appear covered from 1450 until 1530 approximately.

A summary of the above results:

- material composition suggested an origin from Northern Europe; - the Virgin Mary is depicted in a blue dress and a read cloak;

- the Child appears covered by the white drapery, suggests a period of production that encompass from 1500 to 1550, compatible with Jan Massys hypothesis or any other north contemporary artist maybe from Antwerp. 


\begin{tabular}{|c|c|c|c|c|c|c|}
\hline \multicolumn{7}{|c|}{ North Europe } \\
\hline \multicolumn{3}{|c|}{ Child Drapery } & \multicolumn{4}{|c|}{ Virgin Mary drapery colours } \\
\hline \multirow{6}{*}{$\begin{array}{l}1450 \\
\text { uniformity }\end{array}$} & C & $\mathbf{U}$ & D & $\mathrm{Cl}$ & & \multirow{3}{*}{1450} \\
\hline & $\mathrm{x}$ & & & & \multirow{3}{*}{ less strict } & \\
\hline & $x$ & & & & & \\
\hline & $x$ & & & & & 1500 \\
\hline & $x$ & & & & \multirow{3}{*}{$\begin{array}{c}\text { uniformity } \\
\text { opposite to the Italian tendency }\end{array}$} & \\
\hline & $x$ & & & & & \\
\hline \multirow{2}{*}{$\frac{1530}{\text { uniformity }}$} & $x$ & & & & & 1530 \\
\hline & & $x$ & & & \multirow[t]{3}{*}{ period of change } & \\
\hline & & $\mathrm{x}$ & & & & \\
\hline 1560 & & $\mathrm{x}$ & & & & 1560 \\
\hline \multirow[t]{2}{*}{ less strict } & & $\mathrm{x}$ & & & \multirow{3}{*}{$\begin{array}{c}\text { uniformity } \\
\text { alla maniera italiana }\end{array}$} & \\
\hline & & $\mathrm{x}$ & & & & \\
\hline 1650 & & $x$ & & & & 1650 \\
\hline \multicolumn{7}{|c|}{ South Europe (Italy) } \\
\hline \multirow{4}{*}{$\begin{array}{l}1450 \\
\text { less strict } \\
1650\end{array}$} & C & $\mathbf{U}$ & D & $\mathrm{Cl}$ & \multirow{4}{*}{ uniformity } & \\
\hline & & $\mathrm{x}$ & & & & 1450 \\
\hline & $x$ & & & & & \\
\hline & & $\mathrm{x}$ & & & & 1650 \\
\hline
\end{tabular}

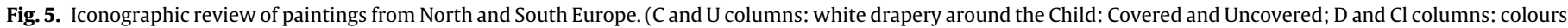
of Virgin's representation: D (dress), Cl (cloak).

Regarding Jan Massys some considerations can be done. The lack of corrections and details of the underdrawing of the panel likely indicates the use of an independent preliminary drawing. That may suggest the work of an apprentice or a workshop copy, also supported by the fact of funding relatively cheap pigments in the composition of the painting. An example of a similar sketch would be the case of the panel of Jan Massys from his period of apprenticeship Saint Jerome (1537, Vienna Kunsthistorisches Museum) [33].

In addition, the use Verditer and Smalt by the Master of the Halflength female figures active in Antwerp between 1527 and 1550 [32] pointed out this circle as the possible origin of the panel.

As a whole, although direct attribution to Jan Massys is not possible, the study has permitted to reduce the uncertainty about the authorship of the painting Virgin with the Child and an Angel.

\section{Conclusions}

Results of the techniques used allowed for the characterisation of the different areas of interest of the panel Virgin with the Child and an Angel, gathering general information about the painting structure and composition [24].

Laser-ablation was proven a very powerful tool to complement classical analytical techniques by the identification of low concentration pigments and thin layers. The LA-ICP/MS technique has allowed the identification of some pigments through the elements detected as As and Co (Smalt) or Hg (Vermillion) as well as their position in the stratigraphy showing their low detection limit and their spatial resolution capability in depth.

The palette and the painting technique points the origin of the painting to an unknown 16th century artist from Northern Europe.

The use of these specific blues, Verditer and Smalt of Cobalt, together with some iconographic features narrows the context of production to North Europe in a period encompassed 1500-1550 most likely in Antwerp and bolster Jan Massys as the author of the panel.

This study reinforces the well known importance to combine material, artistic and historical information to progress on the artworks studies and the key role that may play the minor components.

\section{Acknowledgements}

This research was funded by the Ministry of Science and Innovation (HAR-2011-296654 and HAR-2014-56526). Authors would also like to express their gratitude to the Museu d'Art de Girona (E. Boix, C. Cluselles and J.M.Trullén).

\section{Appendix A. Supplementary data}

Supplementary data associated with this article can be found, in the online version, at http://dx.doi.org/10.1016/j. culher.2017.09.006.

\section{References}

[1] H. Warren, Notes on the life and genius of Bernardino Luini, the night errant, 1, 1892, pp. 24-27.

[2] L. Buijnsters-Smets, Jan Massys: een Antwerps schilder uit de zestiende eeuw, Centraal Boekhuis, 1995.

[3] R. Bordalo, P.J. Morais, C.R.T. Young, R.M. Almeida, Characterisation of laserinduced physical alterations of pigmented oil, 2012, pp. 47-59.

[4] J. Pérez-Arantegui, B. Montull, M. Resano, J.M. Ortega, Materials and technological evolution of ancient cobalt-blue-decorated ceramics: Pigments and work patterns in tin-glazed objects from Aragon (Spain) from the 15 th to the 18th century AD, J. Eur. Ceram. Soc 29 (2009) 2499-2509, http://dx.doi.org/10.1016/j.jeurceramsoc.2009.03.004.

[5] J. Koch, D. Günther, Review of the state-of-the-art of laser ablation inductively coupled plasma mass spectrometry, Appl. Spectrosc. 65 (2011) 155-162, http://dx.doi.org/10.1366/11-06255.

[6] D. Asogan, B.L. Sharp, C.J.P. O' Connor, D.A. Green, R.W. Hutchinson, An open, non-contact cell for laser ablation-inductively coupled plasma-mass spectrometry, J. Anal. At. Spectrom. 24 (2009) 917, http://dx.doi.org/10.1039/b904850b.

[7] T. Kántor, E. Király, É. Bertalan, A. Bartha, Gas-flow optimization studies on brass samples using closed and open types of laser ablation cells in inductively coupled plasma mass spectrometry, Spectrochim. Acta Part B At. Spectrosc. 68 (2012) 46-57, http://dx.doi.org/10.1016/j.sab.2012.01.012.

[8] B. Giussani, D. Monticelli, L. Rampazzi, Role of laser ablation-inductively coupled plasma-mass spectrometry in cultural heritage research: a review, Anal. Chim. Acta. 635 (2009) 6-21, http://dx.doi.org/10.1016/j.aca.2008.12.040.

[9] B. Wagner, W. Jędral, Open ablation cell for LA-ICP-MS investigations of historic objects, J. Anal. At. Spectrom. 26 (2011) 2058, http://dx.doi.org/10.1039/c1ja10137d.

[10] W. Devos, C. Moor, P. Lienemann, C. Du, Determination of impurities in antique silver objects for authentication by laser ablation inductively coupled plasma mass spectrometry (LA-ICP-MS), 1999, pp. 621-626.

[11] N. Yu, Y. Song, Y. Yang, Q. Ma, C. Wang, Study on the glasswares discovered in the underground palace of the Da Bao En Temple in the North Song Dynasty (AD960-AD1127) in Nanjing, China, Sci. China Technol. Sci. 55 (2012) 2006-2012, http://dx.doi.org/10.1007/s11431-012-4870-1. 
[12] T. Zhu, W. Sun, H. Zhang, H. Wang, G. Kuang, L. Lv, Study on the Provenance of Xicun Qingbai Wares From the Northern Song Dynasty of China, Archaeometry 54 (2012) 475-488, http://dx.doi.org/10.1111/j.1475-4754.2011.00636.x.

[13] R. Kovacs, K. Nishiguchi, K. Utani, D. Günther, Development of direct atmospheric sampling for laser ablation-inductively coupled plasma-mass spectrometry, J. Anal. At. Spectrom. 25 (2010) 142, http://dx.doi.org/10.1039/b924425e.

[14] D. Martens, Note sur Jan Massys : une récente monographie et un tableau méconnu conservé a Gérone, D’art Rev. Del Dep. d'Història l'Art. 21 (1995) 203-208.

[15] E. Marin, a. Padró, a. Miquel, J.F. Garcia, Characterization of paintings by laser ablation-inductively coupled plasma-mass spectrometry, Anal. Lett. 48 (2014) 167-179, http://dx.doi.org/10.1080/00032719.2014.921823.

[16] L. Robinet, M. Spring, S. Pag, D. Vantelon, N. Trcera, Investigation of the discoloration of Smalt pigment in historic paintings by micro-X-ray absorption spectroscopy at the Co K-Edge, Anal. Chem. 83 (2011) 5145-5152.

[17] M. Spring, C. Higgitt, D. Saunders, Investigation of pigment-medium interaction processes in oil paint containing degradated samlt, Natl. Gall. Tech. Bull. 26 (2005) 56-70

[18] R. Billinge, L. Campbell, J. Dunkerton, S. Foister, J. Kirby, J. Pilc, A. Roy, M. Spring, R. White, Methods and materials of Northern European painting in the National Gallery, 1400-1550, Natl. Gall. Tech. Bull. 18 (1997) 6-52.

[19] V. Antunes, A. Candeias, M.J. Oliveira, S. Longelin, V. Serrão, A.I. Seruya, J. Coroado, L. Dias, J. Mirão, M.L. Carvalho, Characterization of gypsum and anhydrite ground layers in 15th and 16th centuries Portuguese paintings by Raman Spectroscopy and other techniques, J. Raman Spectrosc. (2014), http://dx.doi.org/10.1002/jrs.4488.

[20] V. Antunes, MJ. Oliveira, H. Vargas, A. Candeias, A. Seruya, L. Dias, V. Serrão, Coroado, Characterization of glue sizing layers in Portuguese wood paintings from the 15 th and 16th centuries by SEM secondary electron images and mFTIR, Microsc. Microanal. 20 (2014) 66-71.
[21] B. Federspiel, Questions about medieval gesso grounds, in: Hist. Paint. Tech. Mater. Sudio Pract., The GettyConservation Institute, Leiden, 1995, pp. 58-64.

[22] M.D. Gayo, M. Janer, Evolución de las preparaciones en la pintura sobre lienzo de los siglos XVI y XVII en España, Boletín del Museu Del Prado. 28 (2010) 39-59.

[23] R.J. Gettens, M.E. Mrose, Calcium sulphate minerals in the grounds of Italian paintings, Stud. Conserv. 1 (1954) 174, http://dx.doi.org/10.2307/1505020.

[24] M.F.A. Boston, CAMEO, Conservation \& Art Materials Encyclopedia Online, (n.d.). http://cameo.mfa.org/wiki/Main_Page (accessed March 3, 2015).

[25] R.D. Harley, Artist's Pigments c 1600-1835, 2nd ed., Archetype Publications, London, 2001

[26] J. Gettens, E. West, Azurite and Blue Verditer, Stud. Conserv. 11 (1966) 57-60.

[27] D. Bomford, A. Roy, A. Smith, The techniques of dieric bouts: two paintings contrasted, Natl. Gall. Tech. Bull. 10 (1986).

[28] H. Pearson, A. Thom, Job and his comforters: a comprehensive report based on technical and art historical analysis. London: The Courtauld institute of art research forum: conservation and art historical analysis, 2011.

[29] J. Plesters, A preliminary note on the incidence of discolouration of Samlt in oil media, Stud. Conserv. 14 (1969) 62-74.

[30] B. Mühlethaler, J. Thissen, Smalt, Stud. Conserv. 14 (1969) 47-61.

[31] A. Burmester, C. Krekel, The relationship between Albrecht Durer's palette and Fifteenth/Sixteenth century pharmacy lists: the use of Azurite and Ultramar, Stud. Conserv. 43 (1998) 101-105.

[32] A. Križnar, M. Valme del, F. Paz de la, M.Á. Respaldiza, M. Vega, A Panel painting by the master of female half-lengths analysed by portable XRF, Coalition 21 (2011) 2-8.

[33] M.C. Galassi, Dendrochronology and Infrared Examination of Jan Massys' Oeuvre, in: Quest Orig. Underdrawing Technol. Paint, Symp. XVI, Paris, 2006, pp. $55-63$. 